\title{
Nanocellulose Production Using Ionic Liquids with Enzymatic Pretreatment
}

\author{
Marta Babicka $^{1}$, Magdalena Woźniak ${ }^{1}\left(\mathbb{D}\right.$, Kinga Szentner $^{1}{ }^{(\mathbb{D}}$, Monika Bartkowiak ${ }^{2}$, Barbara Peplińska $^{3}(\mathbb{D}$, \\ Krzysztof Dwiecki ${ }^{4}$, Sławomir Borysiak ${ }^{5}$ (D) and Izabela Ratajczak ${ }^{1, *}$
}

1 Department of Chemistry, Faculty of Forestry and Wood Technology, Poznań University of Life Sciences, Wojska Polskiego 75, 60625 Poznań, Poland; marta.babicka21@gmail.com (M.B.); magdalena.wozniak@up.poznan.pl (M.W.); kinga.szentner@up.poznan.pl (K.S.)

2 Department of Chemical Wood Technology, Faculty of Forestry and Wood Technology, Poznań University of Life Sciences, Wojska Polskiego 38/42, 60627 Poznań, Poland; monika.bartkowiak@up.poznan.pl

3 NanoBioMedical Centre, Adam Mickiewicz University, Wszechnicy Piastowskiej 3, 61614 Poznań, Poland; barp@amu.edu.pl

4 Department of Food Biochemistry and Analysis, Faculty of Food Science and Nutrition, Poznań University of Life Sciences, Mazowiecka 48, 60623 Poznań, Poland; krzysztof.dwiecki@up.poznan.pl

5 Institute of Chemical Technology and Engineering, Poznan University of Technology, Berdychowo 4, 60965 Poznań, Poland; slawomir.borysiak@put.poznan.pl

* Correspondence: izabela.ratajczak@up.poznan.pl

Citation: Babicka, M.; Woźniak, M.; Szentner, K.; Bartkowiak, M.;

Peplińska, B.; Dwiecki, K.; Borysiak, S.; Ratajczak, I. Nanocellulose Production Using Ionic Liquids with Enzymatic Pretreatment. Materials 2021, 14, 3264. https://doi.org/ $10.3390 /$ ma14123264

Academic Editor: Debora Puglia

Received: 11 May 2021

Accepted: 10 June 2021

Published: 12 June 2021

Publisher's Note: MDPI stays neutra with regard to jurisdictional claims in published maps and institutional affiliations.

Copyright: (c) 2021 by the authors. Licensee MDPI, Basel, Switzerland. This article is an open access article distributed under the terms and conditions of the Creative Commons Attribution (CC BY) license (https:/ / creativecommons.org/licenses/by/ $4.0 /)$.
Abstract: Nanocellulose has gained increasing attention during the past decade, which is related to its unique properties and wide application. In this paper, nanocellulose samples were produced via hydrolysis with ionic liquids (1-ethyl-3-methylimidazole acetate (EmimOAc) and 1-allyl3-methylimidazolium chloride (AmimCl)) from microcrystalline celluloses (Avicel and Whatman) subjected to enzymatic pretreatment. The obtained material was characterized using Fourier transform infrared spectroscopy (FTIR), X-ray diffraction (XRD), dynamic light scattering (DLS), scanning electron microscopy (SEM), and thermogravimetric analysis (TG). The results showed that the nanocellulose had a regular and spherical structure with diameters of 30-40 nm and exhibited lower crystallinity and thermal stability than the material obtained after hydrolysis with Trichoderma reesei enzymes. However, the enzyme-pretreated Avicel had a particle size of about $200 \mathrm{~nm}$ and a cellulose II structure. A two-step process involving enzyme pretreatment and hydrolysis with ionic liquids resulted in the production of nanocellulose. Moreover, the particle size of nanocellulose and its structure depend on the ionic liquid used.

Keywords: nanocellulose; ionic liquids; Trichoderma reesei; enzymatic hydrolysis

\section{Introduction}

Nanocellulose has gained increasing attention during the past decade, as confirmed by the number of patents and scientific papers related to its properties, production methods, and potential applications [1,2]. Cellulose nanocrystals have found applications in various fields, for example as food packaging, biodegradable polymers, biomedical utilization (including drug delivery, substituted implants, biocatalyst or tissue regeneration), wood adhesives, or fillers and additives to nanocomposites [2-10]. Nanocellulose-based polymer composites have potential applications as adsorptive, filtering, and decontaminating materials (including for water treatment, air purification, or microbe and viral decontamination), as well as materials in binders, separators, and electrodes of energy conservation devices and energy capture devices, e.g., as $\mathrm{CO}_{2}$ separators [8,11-15]. The wide application of nanocellulose is connected with its unique properties, such as its high surface area, light weight, low density, biodegradability, biocompatibility, and outstanding strength properties [16-18]. 
Numerous methods are applied to produce cellulose with nanometric dimensions from different lignocellulose materials, including chemical (e.g., with the use of acids and bases) and physical (e.g., grinding, grating, or with the use of high-power lasers) methods [19-21]. A common method of nanocellulose production is acid hydrolysis, along with its modifications, whereby sulfuric, hydrobromic, and hydrochloride acids are usually used in the process of cellulose hydrolysis $[8,22,23]$. However, acid hydrolysis is not considered an environmentally friendly method due to the use of large amounts of solvents, which generate a considerable volume of sewage that requires treatment and contributes to the corrosion of reactors. Moreover, acid hydrolysis is characterized by the low efficiency of the nanocellulose production and the formation of cellulose nanocrystals with reduced thermal stability [24-26].

An eco-friendly alternative method of nanocellulose production is the application of ionic liquids or enzymes, since these methods do not generate hazardous waste, as is the case with acid hydrolysis. Different classes of enzymes have been applied in nanocellulose preparations, including cellulases, xylanases, and lytic polysaccharide monooxygenases [27]. However, cellulases, which are produced by cellulolytic organisms, including fungal species such as Aspergillus, Trichoderma, or Clostridium, are the most commonly used in preparation of nanocellulose $[27,28]$. It is generally recognized that complete hydrolysis of cellulose to glucose requires a synergistic action of at least two of the three groups into which cellulases are divided, namely endoglucanases, exoglucanases, and cellobiohydrolases [1,29]. However, for the production of nanocellulose, endoglucanases are of greatest interest due to their action on amorphous cellulose [30]. It should also be emphasized that the efficiency of the enzymatic hydrolysis process depends on the types of cellulolytic enzymes that determine the sizes of nanometric particles, as well as their polydispersion [28]. According to data from the literature, enzymes are used in the extraction of nanometric cellulose, both alone or combined with chemical or mechanical methods [22,27,31-38]. Moreover, the efficiency of enzymatic cellulose hydrolysis depends on many other factors, such as the crystallinity, average molecular weight, polymorphism, and lignin or hemicellulose contamination [39-41].

Ionic liquids, often referred to as green solvents, have been used in the production of nanocellulose [42-45]. Ionic liquids (ILs) are generally defined as salts that melt below $100{ }^{\circ} \mathrm{C}$ and are completely composed of ions. Interestingly, ILs have many attractive properties such as chemical and thermal stability, low melting points, non-volatility and non-flammability, low vapor pressures, and recyclability [46,47]. Various types of ionic liquids are used in nanocellulose hydrolysis, including 1-butyl-3-methylimidazolium hydrogen sulfate, 1-butyl-3-methylimidazolium chloride, and 1-ethyl-3-methylimidazole chloride [23,48-53]. The production of nanocellulose using ionic liquids has numerous benefits, including the potential to use atmospheric pressure, small amounts of solvents, the potential for regeneration of ionic liquids, and working with an odorless and relatively safe solvent. On the other hand, this method also has disadvantages, which include the relatively high costs of ionic liquids and the unsatisfactory efficiency of the extraction process [51,54-59].

Combinations of methods have been used to increase the efficiency of the nanocellulose production process. The aim of pretreatment is to bring the cellulose polymers to an appropriate form that will increase the efficiency of the subsequent process of nanocellulose production itself. Pretreatment can be a physical or chemical process; most often it is associated with reducing the particle size of the cellulose, increasing the porosity and surface area, or reducing the crystallinity $[60,61]$. Prior to enzymatic hydrolysis reactions, lignocellulosic materials are pretreated using various methods, including milling, swelling treatment, steam explosion, sonification, or treatment with a aqueous sodium hydroxide solution and ionic liquids $[22,31,37,62,63]$.

In our paper, we use enzymatic hydrolysis of cellulosic materials as a preliminary stage of nanocellulose preparation with the application of ionic liquids. To our knowledge, this is the first time that enzymatic hydrolysis has been combined with treatment with ionic liquids 
to obtain nanocellulose, where enzymatic hydrolysis is the pretreatment step. Therefore, the aim of the study is to produce nanometric cellulose by pretreatment with the cellulolytic enzyme from Trichoderma reesei, followed by treatment with two ionic liquids: 1-ethyl-3methylimidazole acetate (EmimOAc) and 1-allyl-3-methylimidazolium chloride (AmimCl). The obtained material is characterized using Fourier transform infrared spectroscopy (FTIR), X-ray diffraction (XRD), dynamic light scattering (DLS), thermogravimetric analysis (TG), and scanning electron microscope (SEM).

\section{Materials and Methods}

\subsection{Materials}

Microcrystalline cellulose: Avicel PH-101 and Whatman cellulose filter paper No. 1 were purchased from Sigma Aldrich Chemie GmbH (Darmstadt, Germany). The cellulolytic enzyme from the microscopic fungus Trichoderma reesei ATCC 26921 with an activity of 700 units / $\mathrm{g}$ and the ionic liquids 1-allyl-3-methylimidazolium chloride ( $\geq 97.0 \%)$ and 1ethyl-3-methylimidazolium acetate $(\geq 95.0 \%)$ were also purchased from Sigma Aldrich Chemie GmbH (Darmstadt, Germany).

\subsection{Pretreatment of Cellulose with Cellulolytic Enzyme}

The cellulose material (Avicel and Whatman) was added to a citrate buffer (50 mM, $\mathrm{pH}=4.8)$ at a ratio of $50: 1(\mathrm{mg} / \mathrm{mL})$ and was incubated for $30 \mathrm{~min}$ at $50{ }^{\circ} \mathrm{C}$ with a shaking speed of $150 \mathrm{rpm} / \mathrm{min}$ (Incubated Shaker, Lab Companion, JeioTech, Korea). Afterwards, the cellulolytic enzyme diluted in the citrate buffer (1:50 by volume) was added to the cellulose material at a ratio of $1: 2$ by volume. The mixture was incubated at $50{ }^{\circ} \mathrm{C}$ with a shaking speed of $150 \mathrm{rpm}$ for $30 \mathrm{~min}$. The reaction was stopped by boiling the sample for $5 \mathrm{~min}$. Next, the samples were centrifuged at $1000 \mathrm{rpm} / \mathrm{min}$ for $15 \mathrm{~min}$ (Universal 320, Andreas Hettich GmbH and Co. KG, Tuttlingen, Germany) and washed with deionized water. The solid cellulose residue was dried in a laboratory dryer (Pol-Eko-Aparatura, Wodzisław Śląski, Poland) and used for further analysis.

\subsection{Preparation of Nanocellulose by Ionic Liquids}

The cellulose material (Avicel and Whatman) after pretreatment with the Trichoderma reesei enzyme was mixed with ionic liquids ((EmimOAc) and $(\mathrm{AmimCl}))$ at a ratio of $1: 5$ by weight. The reactions were run until the material had a homogeneous mix ( $15 \mathrm{~min})$ at $80^{\circ} \mathrm{C}$, under intense stirring using a heating mantle with magnetic stirring (ChemLand, Stargard, Poland). The reaction was carried out without solvent. The reaction was stopped by adding $15 \mathrm{~mL}$ of an acetone and water mixture (1:1) to the reaction mixture. The products of reactions were washed with the acetone and water mixture, filtered, and dried initially at room temperature and finally over $\mathrm{P}_{2} \mathrm{O}_{5}$ (Sigma Aldrich Chemie $\mathrm{GmbH}$, Darmstadt, Germany).

\subsection{Methods}

\subsubsection{FTIR Spectroscopy}

Fourier transform infrared spectroscopy was used to characterize the obtained materials and determine their chemical structure. All samples $(1 \mathrm{mg})$ were mixed with $\mathrm{KBr}$ (200 mg) (Sigma Aldrich Chemie GmbH, Darmstadt, Germany) and analyzed in the pastille form. Spectra were recorded in the range of $4000-500 \mathrm{~cm}^{-1}$, with a resolution of $2 \mathrm{~cm}^{-1}$, and 16 scans were recorded on a Nicolet iS5 spectrophotometer (Thermo Fisher Scientific, Waltham, MA, USA).

\subsubsection{XRD Analysis}

The supermolecular structures of cellulose samples after enzymatic hydrolysis and enzyme-pretreated cellulose treated with ionic liquids were analyzed using the $\mathrm{X}$-ray diffraction (XRD) analysis. The samples were determined using a TUR M-62 X-ray diffractometer (Carl Zeiss AG, Jena, Germany) with a copper anode. The wavelength of the $\mathrm{Cu}$ 
$K_{\alpha}$ radiation source was $1.5418 \AA$ and the spectra were obtained at $30 \mathrm{~mA}$ with an accelerating voltage of $40 \mathrm{kV}$. The diffraction pattern was recorded between 5 and $30^{\circ}$ ( $2 \theta$-angle range) in the step of $0.04^{\circ} / 3 \mathrm{~s}$. Deconvolution of peaks was performed using the method proposed by Hindeleh and Johnson [64] and improved and programmed by Rabiej [65]. After separation of XRD lines, the degrees of crystallinity $\left(X_{c}\right)$ of cellulose samples were determined by comparing the areas under crystalline peaks and the amorphous curve.

\subsubsection{DLS Analysis}

The particle sizes (expressed as the hydrodynamic diameter) of cellulose samples were determined using the DLS method, using a Zetasizer Nano ZS-90 instrument (Malvern, UK). Before analysis, the tested materials were mixed $(2 \mathrm{mg})$ with deionized water $(5 \mathrm{~mL})$ and treated using an ultrasound bath (Polsonic, Warsaw, Poland) for $25 \mathrm{~min}$.

\subsubsection{SEM Analysis}

The surface morphologies of micro- and nanocrystalline cellulose were examined using the SEM method. Images were taken with the use of a JEOL JSM-7001F TTLS scanning electron microscope (JEOL Ltd., Tokyo, Japan) by applying the accelerating voltage of $5 \mathrm{kV}$ and a secondary electron (SEI) detector. The samples were placed on a carbon tape and investigated without coating.

\subsubsection{TG Analysis}

Thermogravimetric analysis was performed on the Netzsch STA 449 F5 Jupiter apparatus (Erich NETZSCH GmbH and Co. Holding KG, Selb, Germany). The tested cellulose samples $(15 \pm 1 \mathrm{mg})$ were heated at the rate of $10^{\circ} \mathrm{C} / \mathrm{min}$ to the assumed temperature of $600{ }^{\circ} \mathrm{C}$. The analyses were performed in an atmosphere of helium flowing through the furnace space at a rate of $15 \mathrm{~mL} / \mathrm{min}$. Thermogravimetric curves (TG) and differential thermogravimetric curves (DTG) were recorded on the thermograms. The former illustrate the dependence of the change in mass (mass loss) on temperature, while the latter illustrate the rate of this change.

\section{Results and Discussion}

\subsection{FTIR Analysis}

In the first stage of the research, the chemical structures of the cellulose samples were determined using Fourier transform infrared spectroscopy (FTIR). The FTIR spectra of the cellulose materials after enzymatic hydrolysis and the materials obtained after the two-step nanocellulose production process (pretreatment with the enzyme and treatment with ionic liquids) are shown in Figures 1 and 2.

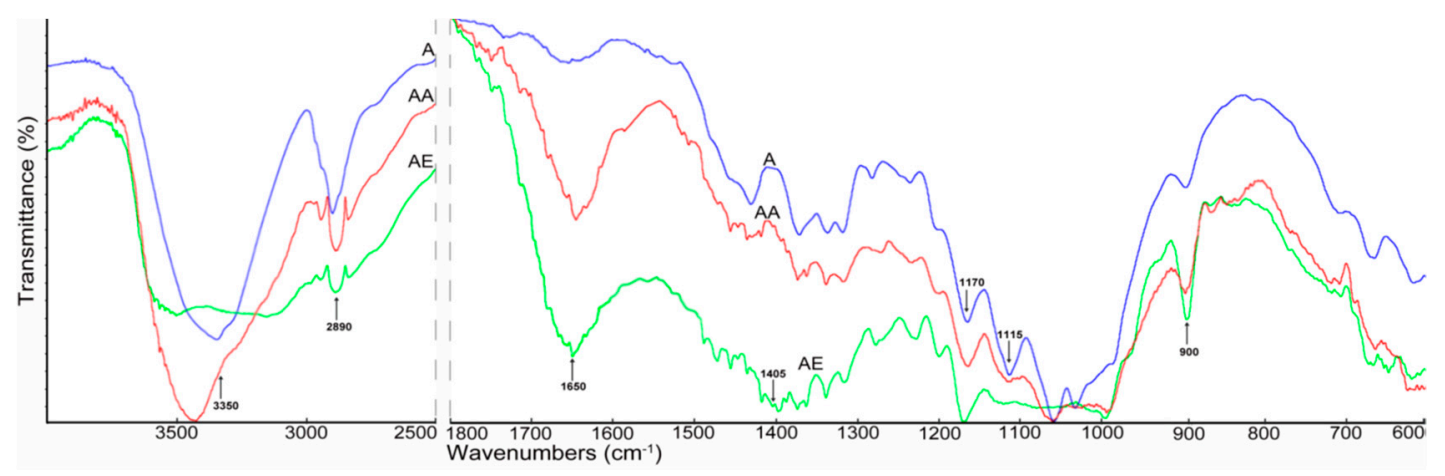

Figure 1. FTIR spectra of (A) enzyme-pretreated Avicel cellulose, (AA) enzyme-pretreated Avicel cellulose treated with $\mathrm{AmimCl}$, and (AE) enzyme-pretreated Avicel cellulose treated with EmimOAc. 


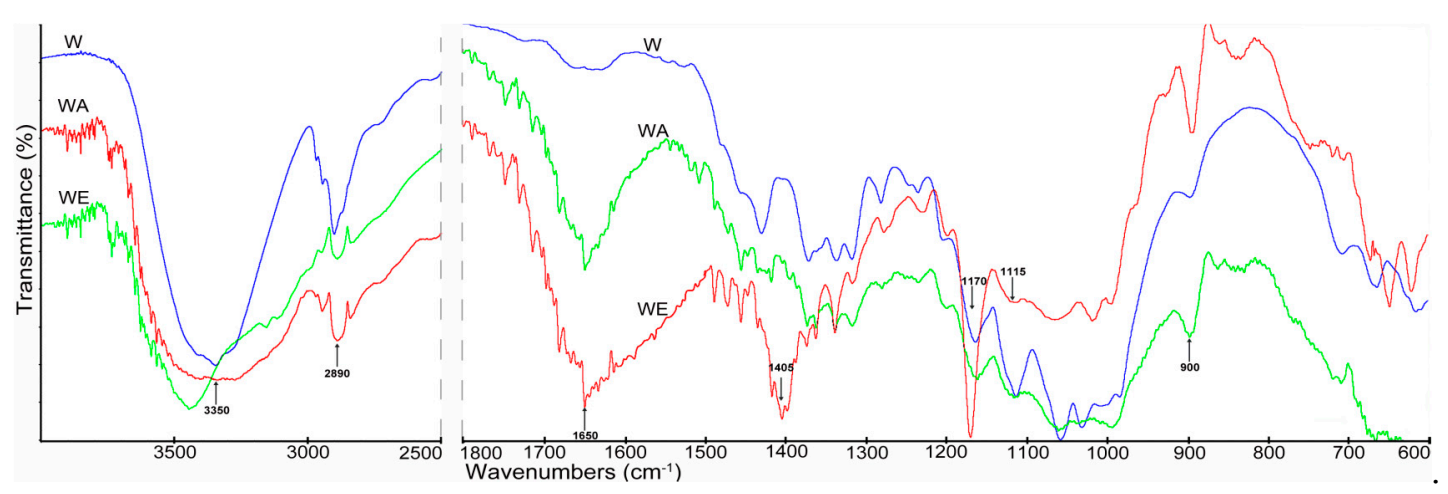

Figure 2. FTIR spectra of (W) enzyme-pretreated Whatman cellulose, (WA) enzyme-pretreated Whatman cellulose treated with AmimCl, and (WE) enzyme-pretreated Whatman cellulose treated with EmimOAc.

All cellulose samples (Avicel and Whatman), including those after enzyme hydrolysis and enzyme-pretreated cellulose hydrolyzed with ionic liquids, presented a broad band in the region of 3350-3480 $\mathrm{cm}^{-1}$, which can be attributed to the hydrogen bond O-H stretching vibrations and flexural vibration of intra- and intermolecular hydrogen bonds $[47,66]$. The changes in intensity of peaks in this region observed in the spectra of cellulose treated with ionic liquids compared to the spectra of samples after enzyme hydrolysis may have been connected to changes in the number and strength of hydrogen bonds. The band at $2900 \mathrm{~cm}^{-1}$ attributed to $\mathrm{C}-\mathrm{H}$ stretching vibrations was observed in the spectra of all cellulose samples; however, the samples treated with ionic liquids show higher intensities [23,47]. The band at $1650 \mathrm{~cm}^{-1}$ visible in the spectra of cellulose treated with ionic liquids was connected with $-\mathrm{OH}$ bending of absorbed water $[23,47,67]$. The intensity of the band at $1650 \mathrm{~cm}^{-1}$ was higher for cellulose samples treated with ionic liquids than for samples treated with the cellulosic enzyme. This was associated with the larger surface area of cellulose particles with smaller dimensions (Figure 3), and thus the greater ability to adsorb moisture. Moreover, significant changes were found within the vibration bands of the amorphous region at $900 \mathrm{~cm}^{-1}$ and crystalline regions at $1405 \mathrm{~cm}^{-1}$. The changes indicated a decrease in cellulose crystallinity after the applied material treatment. These observations were confirmed by the XRD analysis (Table 1). The peaks at $1170 \mathrm{~cm}^{-1}$ and $900 \mathrm{~cm}^{-1}$ were connected with $\mathrm{C}-\mathrm{O}$ stretching or $\mathrm{O}-\mathrm{H}$ bending and the glycosidic $\mathrm{C}_{1}-\mathrm{H}$ deformation mode, respectively [48]. In turn, the bands at $1405 \mathrm{~cm}^{-1}$ and $1115 \mathrm{~cm}^{-1}$ were attributed to the $\mathrm{C}-\mathrm{H}$ deformation (asymmetric) and $\mathrm{O}-\mathrm{H}$ association band in cellulose, respectively [68]. Moreover, in the spectra of treated cellulose samples, especially samples hydrolyzed with ionic liquids, peaks ranging from 1100 to $550 \mathrm{~cm}^{-1}$ were observed, indicating twisting, wagging, and deformation modes of anhydro-glucopyranose, which represent the characteristic pattern of $\beta$-glucosidic linkages [23,47].

Table 1. The crystallinity index values for the cellulose samples.

\begin{tabular}{cccc}
\hline Samples & The Crystallinity Index (\%) & Samples & The Crystallinity Index (\%) \\
\hline A & 60 & W & 63 \\
AA & 24 & WA & 33 \\
AE & 36 & WE & 39 \\
\hline
\end{tabular}



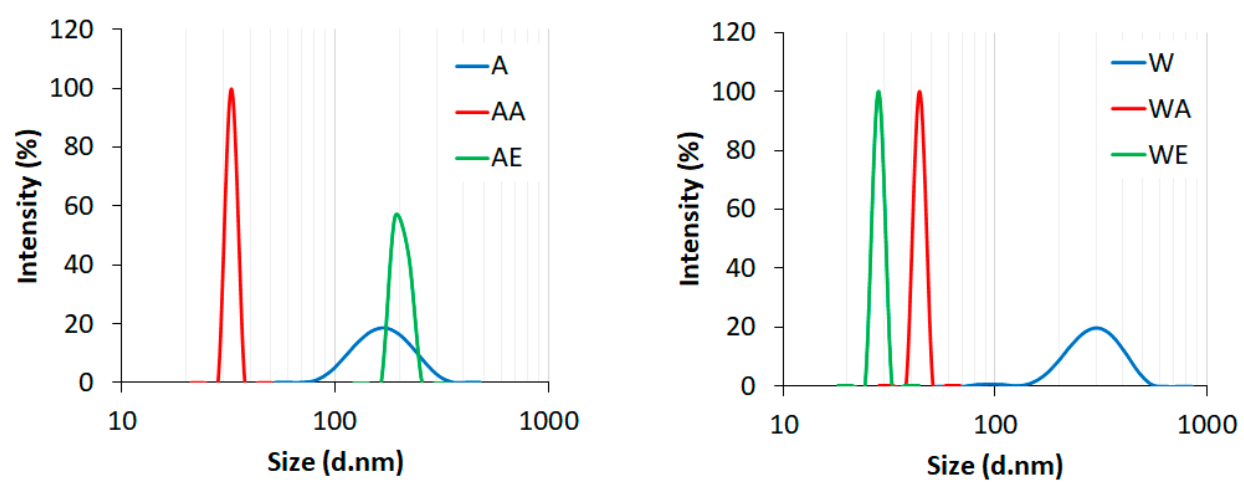

Figure 3. The average particle sizes of (A) enzyme-pretreated Avicel cellulose, (AA) enzymepretreated Avicel cellulose treated with AmimCl, (AE) enzyme-pretreated Avicel cellulose treated with EmimOAc, (W) enzyme-pretreated Whatman cellulose, (WA) enzyme-pretreated Whatman cellulose treated with $\mathrm{AmimCl}$, and (WE) enzyme-pretreated Whatman cellulose treated with EmimOAc.

\subsection{DLS Analysis}

The average particle sizes (hydrodynamic diameter) of the enzyme-pretreated cellulose and nanocellulose samples obtained after the two-step production process as assessed by dynamic light scattering (DLS) are presented in Figure 3.

The enzymatic hydrolysis of cellulosic materials (Avicel and Whatman) resulted in a decrease of the average particle size compared to the starting material, which was micrometric in size. The initial particle size range of Avicel cellulose was $1300-4800 \mathrm{~nm}$, while Whatman cellulose had a particle size range of 700-6400 nm. After enzyme pretreatment, the average size of Avicel cellulose particles was below $200 \mathrm{~nm}$, while the particle size of Whatman cellulose was about $300 \mathrm{~nm}$. However, both of the peaks were wide, indicating high particle size dispersion. According to the data from the literature, the average particle size for cellulose hydrolyzed with the cellulase enzyme was $0.526 \mu \mathrm{m}$; however, $50 \%$ of the particles were smaller than this [66]. The average size range of cellulose nanocrystals obtained via endoglucanase enzyme hydrolysis with two heating models (conventional and microwave-coupled with ultrasonication) was $100 \mathrm{~nm}$ to $3.5 \mu \mathrm{m}$ [69]. In turn, the particle size of nanocellulose prepared through enzymatic hydrolysis with three different pretreatments (ultrasonic treatment, treatment with $\mathrm{NaOH}$, and treatment with DMSO) depended on the pretreatment type. The average size of nanocellulose with ultrasonic pretreatment was $5-6 \mathrm{~nm}$, for nanocellulose prepared by DMSO pretreatment was about $250 \mathrm{~nm}$, while nanocellulose obtained with $\mathrm{NaOH}$ pretreatment contained two particle sizes-one type measuring $25 \mathrm{~nm}$ and the other measuring $250 \mathrm{~nm}$, which were the aggregates [67].

The results presented in Figure 3 indicate a notable shift in the cellulose particle size after treatment with both ionic liquids (except for Avicel cellulose treated with EmimOAc) as compared to the enzyme-pretreated cellulose. In addition, all nanocellulose samples were characterized by much lower particle size dispersions than the samples after enzymatic hydrolysis, confirming the narrow and well-defined peaks presented in Figure 3. The average particle size for enzyme-pretreated Avicel cellulose obtained after hydrolysis with AmimCl (AA) and enzyme-pretreated Whatman cellulose obtained after hydrolysis with EmimOAc (WE) was around $30 \mathrm{~nm}$, while that of enzyme-pretreated Whatman cellulose obtained after hydrolysis with $\mathrm{AmimCl}$ (WA) was around $40 \mathrm{~nm}$. In turn, the nanocellulose obtained by Avicel cellulose hydrolysis with EmimOAc (AE) was characterized by the greater average size of particles (around $200 \mathrm{~nm}$ ) compared to the other nanocellulose samples obtained after hydrolysis with ionic liquids. To sum up, the results of the DLS analysis confirmed that the efficiency of nanocellulose production with enzyme pretreatment is influenced by the type of the initial cellulosic material, as well as the type of ionic liquid used. 


\subsection{SEM Analysis}

The morphologies of the cellulosic materials after enzymatic pretreatment followed by hydrolysis with ionic liquids were examined by SEM analysis. The SEM images are shown in Figure 4.

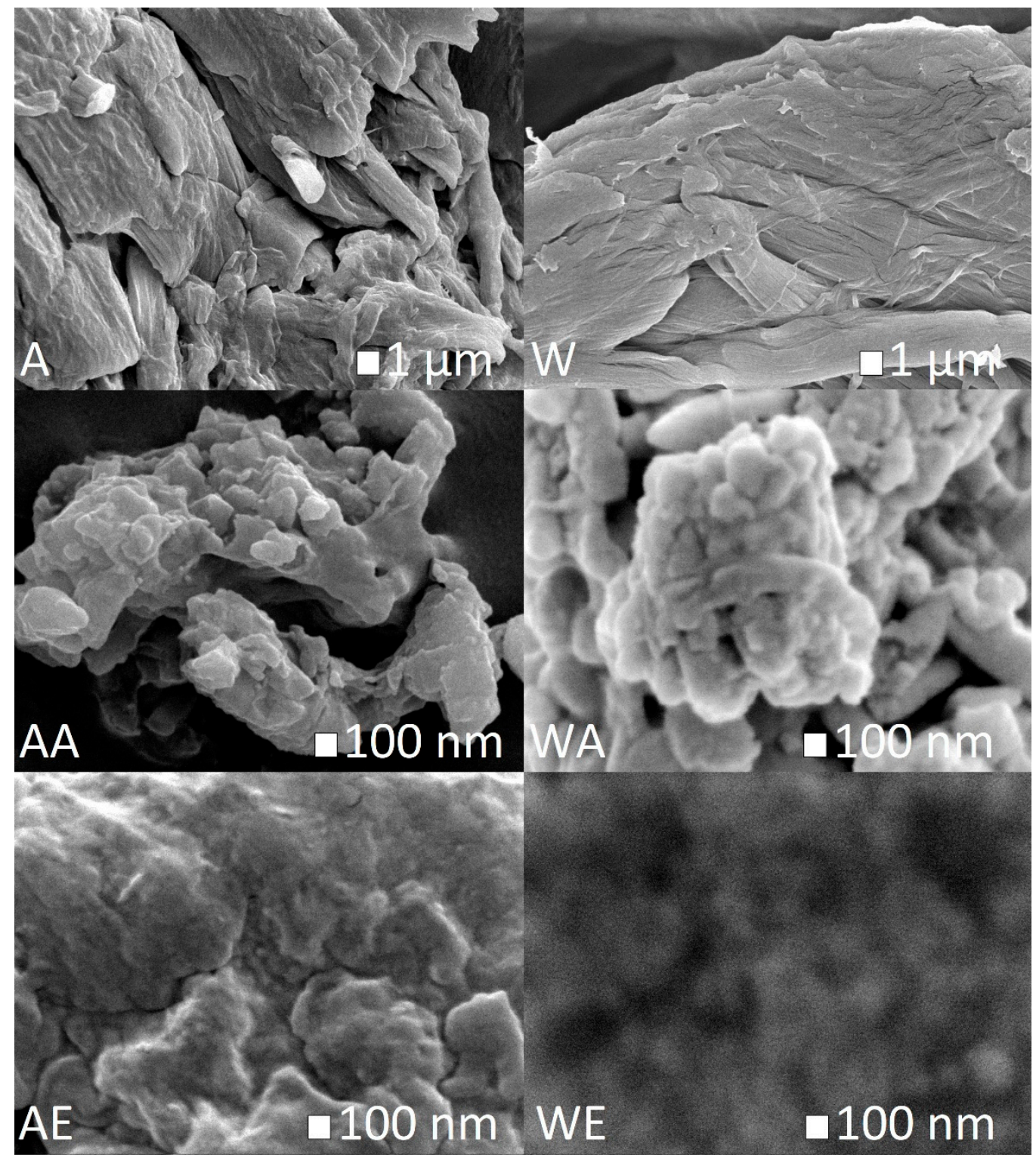

Figure 4. SEM images of (A) enzyme-pretreated Avicel cellulose, (AA) enzyme-pretreated Avicel cellulose treated with AmimCl, (AE) enzyme-pretreated Avicel cellulose treated with EmimOAc, (W) enzyme-pretreated Whatman cellulose, (WA) enzyme-pretreated Whatman cellulose treated with AmimCl, and (WE) enzyme-pretreated Whatman cellulose treated with EmimOAc.

Figure 4 shows that hydrolysis of enzyme-pretreated cellulose (Avicel and Whatman) with both ionic liquids caused changes in the material structure and a reduction of its diameter. The cellulose material after treatment with ionic liquids had a more regular and spherical structure than cellulose hydrolyzed with the Trichoderma reesei enzyme. The spherical structure of obtained nanocellulose is in contrast to the results of other research, where nanocelluloses produced by hydrolysis with an ionic liquid had needle- or rod-like morphologies $[23,44,47,70]$. 


\subsection{XRD Analysis}

The diffraction profiles of enzyme-pretreated cellulose and cellulose after treatment with ionic liquids are shown in Figure 5.
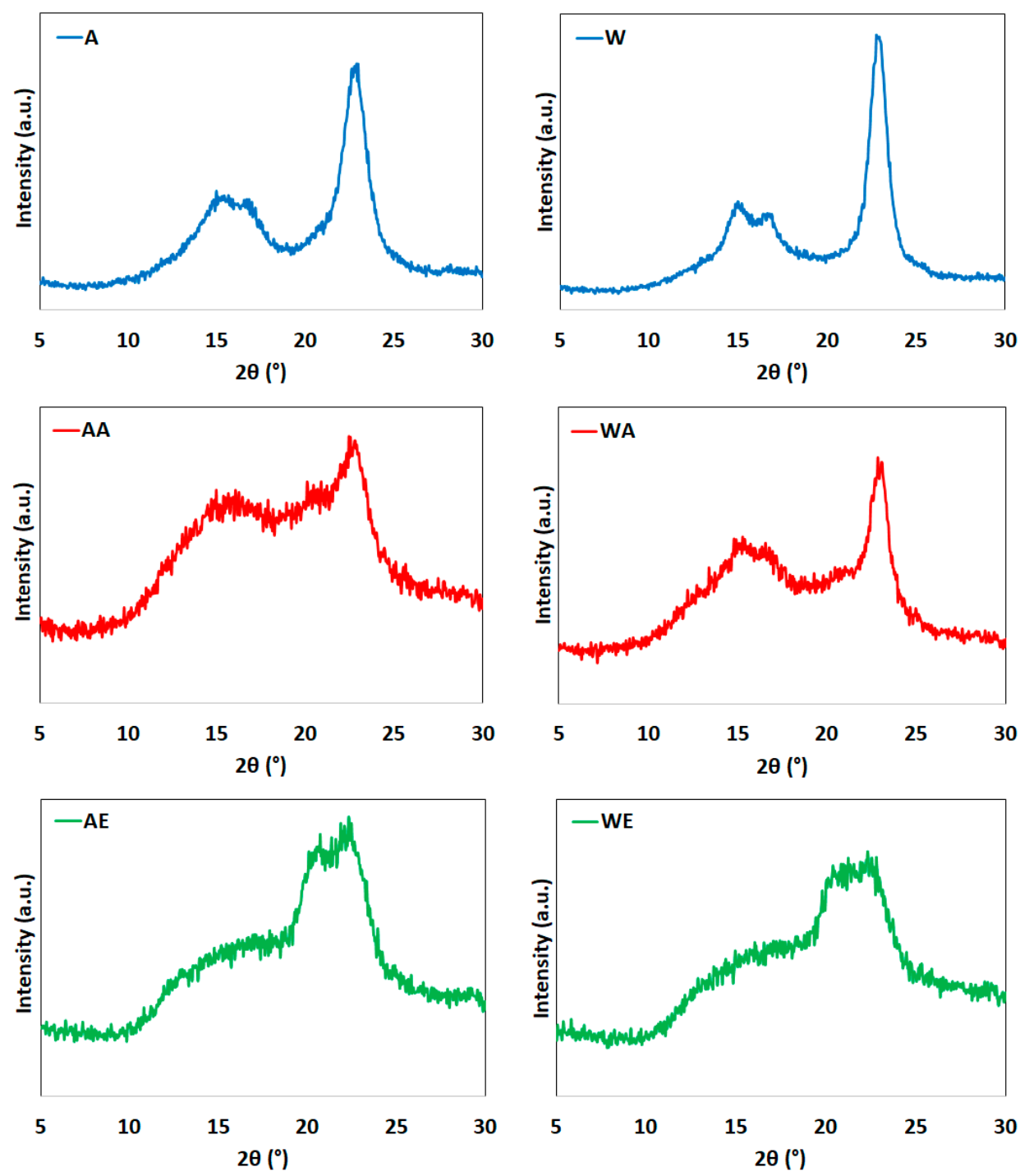

Figure 5. XRD patterns of (A) enzyme-pretreated Avicel cellulose, (AA) enzyme-pretreated Avicel cellulose treated with AmimCl, (AE) enzyme-pretreated Avicel cellulose treated with EmimOAc, (W) enzyme-pretreated Whatman cellulose, (WA) enzyme-pretreated Whatman cellulose treated with AmimCl, and (WE) enzyme-pretreated Whatman cellulose treated with EmimOAc.

The diffractograms of cellulose after enzymatic hydrolysis (Avicel and Whatman) showed peaks characteristic of cellulose I at $2 \theta=15^{\circ}$ (plane 1-10), $17^{\circ}$ (plane 110), and 22.7 (plane 200) [71]. Additionally, these maxima were observed for the enzyme-pretreated cellulose samples treated with $\mathrm{AmimCl}$, although the intensity was much lower.

Unexpectedly, in the case of enzyme-pretreated cellulose treated with EmimOAc, disappearance of the maximum from cellulose I was observed, along with the formation of two maxima at the diffraction angles of $20^{\circ}$ and $22^{\circ}$, the peaks of which came from the lattice planes at (110) and (020), respectively. This indicates the formation of cellulose II and proves that the use of the 1-ethyl-3-methylimidazolium acetate solution resulted in the conversion of polymorphic cellulose I into cellulose II. Data from the literature indicated that the conversion of cellulose I into cellulose II is the result of a mercerization process run in the presence of alkali [72,73]. Additionally, Cheng et al. [74] noted that the use of 1-ethyl- 
3-methylimidazolium acetate for modification of cellulose, switchgrass (Panicum virgatum), pine (Pinus radiata), and eucalyptus (Eucalyptus globulus) affects the formation of cellulose II. The transformation of cellulose I into cellulose II was also noted by Li et al. [75] and by Wang et al. [76] for another ionic liquid, namely 1-butyl-3-methylimidazolium chloride.

Table 1 presents the crystallinity index values for the cellulose samples.

The values of the crystallinity index indicated that enzymatic hydrolysis affected the degree of crystallinity of the raw cellulose material. The crystallinity index values for enzyme-pretreated cellulose were $60 \%$ for Avicel and $63 \%$ for Whatman types compared to $61 \%$ and $75 \%$ for untreated raw Avicel and Whatman cellulose, respectively [44,77]. However, significant changes in the degree of crystallinity were noted for the cellulose samples obtained after hydrolysis with ionic liquids. The calculated crystallinity index values for Avicel cellulose after the reaction with ionic liquids were $24 \%$ (after hydrolysis with AmimCl) and 36\% (after hydrolysis with EmimOAc). The crystallinity values for Whatman cellulose after the reaction with ionic liquids were 33\% (after hydrolysis with $\mathrm{AmimCl}$ ) and 39\% (after hydrolysis with EmimOAc). Among all of the cellulose samples, the nanocellulose sample with the smallest particle size (AA) (Figure 3) had the lowest crystallinity. This indicates that the cellulose chains were broken during the treatment process with ionic liquids, with a consequent reduction in the degree of crystallinity. The reaction of enzyme-pretreated cellulose with $\mathrm{AmimCl}$ caused decreases of the crystallinity index by about $60 \%$ for Avicel cellulose and $48 \%$ for Whatman cellulose compared to the enzyme-pretreated material. Such reductions in the degree of crystallinity for cellulose treated with ionic liquids were previously reported by other authors $[44,70,76]$. The degree of crystallinity of eucalyptus pulp amounting to $70 \%$ was reduced to $36 \%$ by treatment with an ionic liquid, namely BmimCl [76]. The degrees of crystallinity for nanocelluloses obtained from cotton and microcrystalline cellulose treated with $\mathrm{BmimCl}$ were $52 \%$ and $62 \%$ compared to the values of $77 \%$ and $80 \%$ for the native material, respectively [50]. The degree of crystallinity for the nanocellulose obtained with EmimOAc (33\%) was lower than the degree of crystallinity for the nanocellulose obtained in our previous work, where EmimCl (47\%) was used [44].

According to the literature date, the anion of the ionic liquid plays an important role in the dissolution and hydrolysis process of cellulose, which forms hydrogen bonds with -OH groups of cellulose. The hydrogen bonds of the cations of ionic liquid are most likely formed mainly between the $\mathrm{H} 1$ proton of the imidazolium ring and the $\mathrm{C} 6$ and $\mathrm{C} 3$ carbons of the cellulose chain $[78,79]$. The research indicated that the acetate anion forms strong hydrogen bonds, as opposed to the weakly basic chloride anion, which forms weak hydrogen bonds with cellulose $[24,53,78]$.

\subsection{TG Analysis}

The thermogravimetric curve (TG) and its derivative curve (DTG) for enzyme-pretreated celluloses (in Avicel and Whatman forms) hydrolyzed with ionic liquids are shown in Figures 6 and 7, respectively.

Knowledge of the thermostability of nanocellulose is important, e.g., when this material is used as a filler for a biopolymer, where elevated temperatures are required for their production $[27,63,80]$. Raw cellulose is a material with moderate thermal properties, with decomposition temperature ranging between 315 and $400{ }^{\circ} \mathrm{C}$ [81]. The TG and DTG curves for enzyme hydrolyzed cellulose differed from those for enzyme-pretreated cellulose after the reaction with both ionic liquids, which indicated that hydrolysis with ionic liquids results in changes in the characteristic degradation temperatures. All of the tested samples initially showed slight losses of weight at temperatures below $100^{\circ} \mathrm{C}$, which were related to water evaporation [47]. The presence of hydrogen bonds in the tested cellulose materials was confirmed by FTIR analysis (Figure 1). In the curves for all samples, except for the EmimOAc-treated cellulose, a single significant decomposition process was observed, corresponding to the degradation processes, such as dehydration, depolymerization, and degradation of the glycosyl rings, followed by the formation of a 
charred residue [66]. The DTG curve for the enzyme-pretreated Avicel cellulose hydrolyzed with EmimOAc showed a different course of thermal decomposition (two peaks on the DTG curve) and different thermal characteristics (thermal properties) compared to the other cellulose samples. The thermal behavior of this cellulose sample can be explained by the particle size (around $200 \mathrm{~nm}$ ), which was greater than that of the other nanocellulose samples. This may have caused thermal degradation to take place in multiple stages (two peaks) and to be slower (the maximum rates of decomposition are lower compared to the other tested samples, as shown on the y axes $(\% / \mathrm{min})$ for the DTG curves). The onset temperature of degradation $\left(\mathrm{T}_{\text {onset }}\right)$ and the maximum decomposition temperature $\left(T_{\max }\right)$ for the enzyme-pretreated Avicel cellulose were 300 and $358{ }^{\circ} \mathrm{C}$, respectively. In turn, decomposition of the enzyme-pretreated Whatman cellulose took place within a temperature range of $293-379^{\circ} \mathrm{C}$.
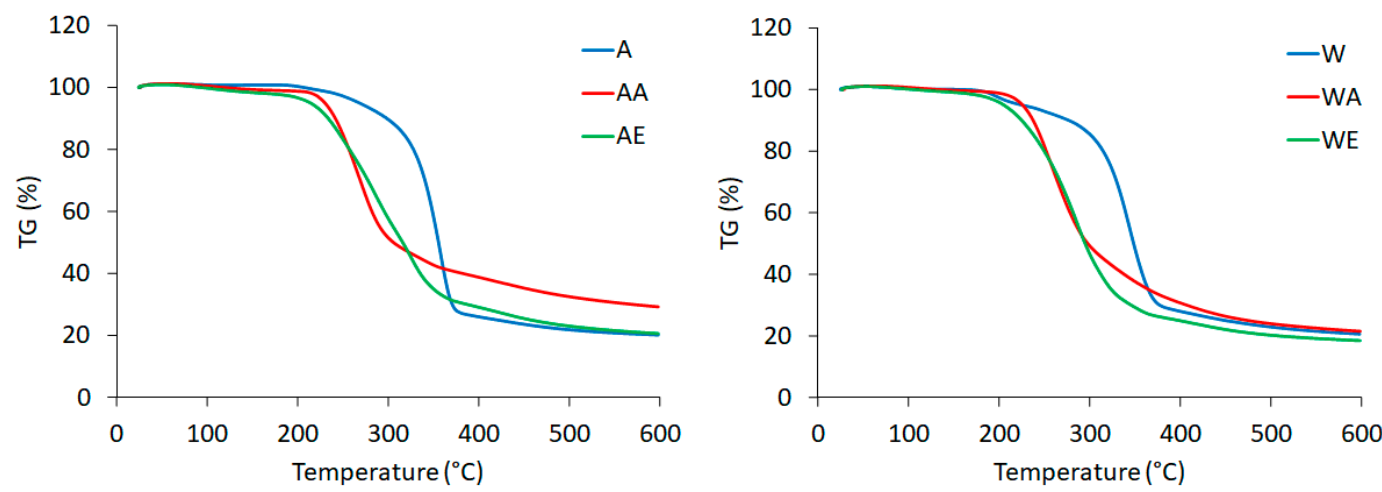

Figure 6. TG curves of (A) enzyme-pretreated Avicel cellulose, (AA) enzyme-pretreated Avicel cellulose treated with AmimCl, (AE) enzyme-pretreated Avicel cellulose treated with EmimOAc, (W) enzyme-pretreated Whatman cellulose, (WA) enzyme-pretreated Whatman cellulose treated with $\mathrm{AmimCl}$, and (WE) enzyme-pretreated Whatman cellulose treated with EmimOAc.
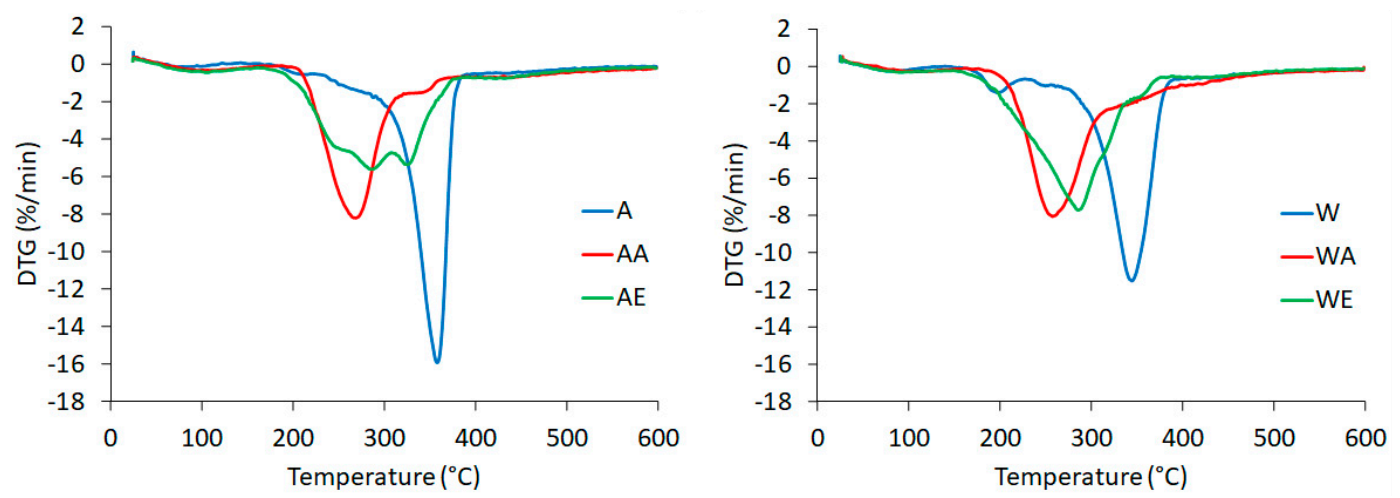

Figure 7. DTG curves of (A) enzyme-pretreated Avicel cellulose, (AA) enzyme-pretreated Avicel cellulose treated with AmimCl, (AE) enzyme-pretreated Avicel cellulose treated with EmimOAc, (W) enzyme-pretreated Whatman cellulose, (WA) enzyme-pretreated Whatman cellulose treated with $\mathrm{AmimCl}$, and (WE) enzyme-pretreated Whatman cellulose treated with EmimOAc.

The degradation behaviors of the enzyme-pretreated celluloses hydrolyzed with ionic liquids presented differences from that of the cellulose treated only with the enzyme, implying that the degradation started at lower temperatures of $211^{\circ} \mathrm{C}$ (Avicel) and $188^{\circ} \mathrm{C}$ (Whatman) for the cellulose treated with AmimCl and $194{ }^{\circ} \mathrm{C}$ (Avicel) and $200{ }^{\circ} \mathrm{C}$ (Whatman) for the cellulose treated with EmimOAc. The beginning of the decomposition for the enzyme-pretreated cellulose after the reaction with ionic liquids at lower temperatures was connected with the lower crystallinity index values of celluloses treated with $\mathrm{AmimCl}$ and EmimOAc. The high surface area of cellulose nanoparticles also reduces their thermal properties because of the greater surface area exposed to high tempera- 
tures [66]. The nanocelluloses obtained using different methods were characterized by varying thermal stability. The onset temperatures for the enzyme-pretreated cellulose after the reaction with both ionic liquids were lower than those for the nanocelluloses obtained from wood $\left(280^{\circ} \mathrm{C}\right)$, maize husk $\left(291^{\circ} \mathrm{C}\right)$, and sugar cane $\left(319^{\circ} \mathrm{C}\right)$, as described in a paper by Onkarappa et al. [68]. In turn, decomposition of cellulose nanocrystals obtained via hydrolysis with sulfuric acid started at around $150^{\circ} \mathrm{C}$, as described by Lu and Hsieh [82]. The nanocellulose obtained by hydrolysis with $\mathrm{BmimCl}$ showed lower thermal stability with a decomposition temperature of $238^{\circ} \mathrm{C}$ as compared to $288^{\circ} \mathrm{C}$ for raw cellulose [75]. Lower thermal stability was also exhibited by the nanocellulose produced by hydrolysis with $\mathrm{BmimHSO}_{4}$ as compared to native microcrystalline cellulose [47].

\section{Conclusions}

The present study has demonstrated that nanocellulose could be produced through hydrolysis with ionic liquids from enzyme-pretreated microcrystalline cellulose. In this study, ionic liquids (1-ethyl-3-methylimidazole acetate (EmimOAc) and 1-allyl-3-methylimidazolium chloride $(\mathrm{AmimCl})$ ) were used. The ionic liquid treatment of the cellulosic material (Avicel and Whatman) obtained after hydrolysis with enzymes from Trichoderma reesei resulted in a decrease of the average particle size compared to the material after enzymatic hydrolysis. The nanocellulose samples were found to have a regular and spherical structure with diameters of about $30-40 \mathrm{~nm}$. The exception was cellulose obtained from the enzymepretreated Avicel cellulose via hydrolysis with EmimOAc, which had a particle size of about $200 \mathrm{~nm}$. The basic cellulose I structure was preserved in cellulose obtained after hydrolysis with the Trichoderma reesei enzyme and nanocellulose obtained through AmimCl treatment. In the case of enzyme-pretreated cellulose treated with EmimOAc, the transformation to cellulose II occurred. All nanocellulose samples showed decreases in crystallinity index values compared to the material after enzymatic hydrolysis. Moreover, treatment with ionic liquids changed the thermal properties of nanocellulose, resulting in decreases in their thermal stability.

Overall, the two-step process involving enzyme pretreatment and hydrolysis with ionic liquids resulted in the production of nanocellulose. The presented results indicate that the particle size of nanocellulose and its structure depend on the ionic liquid used.

Author Contributions: Conceptualization, M.B. (Marta Babicka); methodology, M.B. (Marta Babicka); formal analysis, M.B. (Marta Babicka), K.S., M.B. (Monika Bartkowiak), B.P., K.D. and S.B.; writingoriginal draft preparation, M.B. (Marta Babicka); writing-review and editing, M.W.; supervision, I.R. All authors have read and agreed to the published version of the manuscript.

Funding: The paper was co-financed within the framework of the Ministry of Science and Higher Education program 'Regional Initiative of Excellence' for the years 2019-2022, project no. 005/RID/2018/19. This work was supported by the National Science Center, Poland (Grant number 2014/13/B/NZ9/02442), and additionally was funded in part by the Ministry of Education and Science.

Institutional Review Board Statement: Not applicable.

Informed Consent Statement: Not applicable.

Data Availability Statement: The data reported in this study are available from the authors upon request.

Conflicts of Interest: The authors declare no conflict of interest.

\section{References}

1. Ribeiro, R.S.A.; Pohlmann, B.C.; Calado, V.; Bojorge, N.; Pereira, N. Production of nanocellulose by enzymatic hydrolysis: Trends and challenges. Eng. Life Sci. 2019, 19, 279-291. [CrossRef] [PubMed]

2. Charreau, H.; Cavallo, E.; Foresti, M.L. Patents involving nanocellulose: Analysis of their evolution since 2010. Carbohydr. Polym. 2020, 237, 116039. [CrossRef]

3. Ahankari, S.S.; Subhedar, A.R.; Bhadauria, S.S.; Dufresne, A. Nanocellulose in food packaging: A review. Carbohydr. Polym. 2021, 255, 117479. [CrossRef] [PubMed]

4. Zinge, C.; Kandasubramanian, B. Nanocellulose based biodegradable polymers. Eur. Polym. J. 2020, 133, 109758. [CrossRef] 
5. Moohan, J.; Stewart, S.A.; Espinosa, E.; Rosal, A.; Rodríguez, A.; Larrañeta, E.; Donnelly, R.F.; Domínguez-Robles, J. Cellulose nanofibers and other biopolymers for biomedical applications. A review. Appl. Sci. 2020, 10, 65. [CrossRef]

6. Karimian, A.; Parsian, H.; Majidinia, M.; Rahimi, M.; Mir, S.M.; Samadi Kafil, H.; Shafiei-Irannejad, V.; Kheyrollah, M.; Ostadi, H.; Yousefi, B. Nanocrystalline cellulose: Preparation, physicochemical properties, and applications in drug delivery systems. Int. J. Biol. Macromol. 2019, 133, 850-859. [CrossRef]

7. Bacakova, L.; Pajorova, J.; Bacakova, M.; Skogberg, A.; Kallio, P.; Kolarova, K.; Svorcik, V. Versatile application of nanocellulose: From industry to skin tissue engineering and wound healing. Nanomaterials 2019, 9, 164. [CrossRef]

8. Trache, D.; Tarchoun, A.F.; Derradji, M.; Hamidon, T.S.; Masruchin, N.; Brosse, N.; Hussin, M.H. Nanocellulose: From Fundamentals to Advanced Applications. Front. Chem. 2020, 8. [CrossRef]

9. Abdul Khalil, H.P.S.; Jummaat, F.; Yahya, E.B.; Olaiya, N.G.; Adnan, A.S.; Abdat, M.; Nasir, N.A.M.; Halim, A.S.; Seeta Uthaya Kumar, U.; Bairwan, R.; et al. A review on micro- to nanocellulose biopolymer scaffold forming for tissue engineering applications. Polymers 2020, 12, 2043. [CrossRef]

10. Lengowski, E.C.; Bonfatti Júnior, E.A.; Nishidate Kumode, M.M.; Carneiro, M.E.; Satyanarayana, K.G. Nanocellulose-reinforced adhesives for wood-based panels. Sustain. Polym. Compos. Nanocompos. 2019, 1001-1025. [CrossRef]

11. Nemoto, J.; Saito, T.; Isogai, A. Simple freeze-drying procedure for producing nanocellulose aerogel-containing, high-performance air filters. ACS Appl. Mater. Interfaces 2015, 7, 19809-19815. [CrossRef]

12. Putro, J.N.; Kurniawan, A.; Ismadji, S.; Ju, Y.H. Nanocellulose based biosorbents for wastewater treatment: Study of isotherm, kinetic, thermodynamic and reusability. Environ. Nanotechnol. Monit. Manag. 2017, 8, 134-149. [CrossRef]

13. Zhou, Y.; Khan, T.M.; Liu, J.C.; Fuentes-Hernandez, C.; Shim, J.W.; Najafabadi, E.; Youngblood, J.P.; Moon, R.J.; Kippelen, B. Efficient recyclable organic solar cells on cellulose nanocrystal substrates with a conducting polymer top electrode deposited by film-transfer lamination. Org. Electron. 2014, 15, 661-666. [CrossRef]

14. Mohammed, N.; Grishkewich, N.; Berry, R.M.; Tam, K.C. Cellulose nanocrystal-alginate hydrogel beads as novel adsorbents for organic dyes in aqueous solutions. Cellulose 2015, 22, 3725-3738. [CrossRef]

15. Lasrado, D.; Ahankari, S.; Kar, K. Nanocellulose-based polymer composites for energy applications-A review. J. Appl. Polym. Sci. 2020, 137, 1-14. [CrossRef]

16. Phanthong, P.; Reubroycharoen, P.; Hao, X.; Xu, G.; Abudula, A.; Guan, G. Nanocellulose: Extraction and application. Carbon Resour. Convers. 2018, 1, 32-43. [CrossRef]

17. Abitbol, T.; Rivkin, A.; Cao, Y.; Nevo, Y.; Abraham, E.; Ben-Shalom, T.; Lapidot, S.; Shoseyov, O. Nanocellulose, a tiny fiber with huge applications. Curr. Opin. Biotechnol. 2016, 39, 76-88. [CrossRef] [PubMed]

18. Heise, K.; Kontturi, E.; Allahverdiyeva, Y.; Tammelin, T.; Linder, M.B.; Nonappa; Ikkala, O. Nanocellulose: Recent fundamental advances and emerging biological and biomimicking applications. Adv. Mater. 2021, 33. [CrossRef] [PubMed]

19. George, J.; Sabapathi, S.N. Cellulose nanocrystals: Synthesis, functional properties, and applications. Nanotechnol. Sci. Appl. 2015, 8, 45-54. [CrossRef] [PubMed]

20. Kalia, S.; Dufresne, A.; Cherian, B.M.; Kaith, B.S.; Avérous, L.; Njuguna, J.; Nassiopoulos, E. Cellulose-based bio- and nanocomposites: A review. Int. J. Polym. Sci. 2011, 2011. [CrossRef]

21. Lee, H.V.; Hamid, S.B.A.; Zain, S.K. Conversion of lignocellulosic biomass to nanocellulose: Structure and chemical process. Sci. World J. 2014, 2014. [CrossRef] [PubMed]

22. De Aguiar, J.; Bondancia, T.J.; Claro, P.I.C.; Mattoso, L.H.C.; Farinas, C.S.; Marconcini, J.M. Enzymatic deconstruction of sugarcane bagasse and straw to obtain cellulose nanomaterials. ACS Sustain. Chem. Eng. 2020, 8, 2287-2299. [CrossRef]

23. Man, Z.; Muhammad, N.; Sarwono, A.; Bustam, M.A.; Kumar, M.V.; Rafiq, S. Preparation of cellulose nanocrystals using an ionic liquid. J. Polym. Environ. 2011, 19, 726-731. [CrossRef]

24. Du, H.; Qian, X. The effects of acetate anion on cellulose dissolution and reaction in imidazolium ionic liquids. Carbohydr. Res. 2011, 346, 1985-1990. [CrossRef] [PubMed]

25. Clough, M.T.; Geyey, K.; Hunt, P.A.; Son, S.; Vagt, U.; Welton, T. Ionic liquids: Not always innocent solvents for cellulose. Green Chem. 2014, 1-15. [CrossRef]

26. Handy, S.T.; Okello, M. The 2-position of imidazolium ionic liquids: Substitution and exchange. J. Org. Chem. 2005, 70, 1915-1918. [CrossRef] [PubMed]

27. Michelin, M.; Gomes, D.G.; Romaní, A.; Polizeli, M.d.L.T.M.; Teixeira, J.A. Nanocellulose Production: Exploring the Enzymatic Route and Residues of Pulp and Paper Industry. Molecules 2020, 25, 3411. [CrossRef]

28. Zielińska, D.; Szentner, K.; Waśkiewicz, A.; Borysiak, S. Production of nanocellulose by enzymatic treatment for application in polymer composites. Materials 2021, 14, 2124. [CrossRef] [PubMed]

29. Mussatto, S.; Teixeira, J. Lignocellulose as raw material in fermentation processes. In Current Research, Technology and Education Topics in Applied Microbiology and Microbial Biotechnology; Méndez-Vilas, A., Ed.; Formatex Research Center: Badajoz, Spain, 2010; Volume 2, pp. 897-907, ISBN-13: 978-84-614-6195-0.

30. Josefsson, P.; Henriksson, G.; Wågberg, L. The physical action of cellulases revealed by a quartz crystal microbalance study using ultrathin cellulose films and pure cellulases. Biomacromolecules 2008, 9, 249-254. [CrossRef]

31. Cui, S.; Zhang, S.; Ge, S.; Xiong, L.; Sun, Q. Green preparation and characterization of size-controlled nanocrystalline cellulose via ultrasonic-assisted enzymatic hydrolysis. Ind. Crops Prod. 2016, 83, 346-352. [CrossRef] 
32. Siqueira, G.A.; Dias, I.K.R.; Arantes, V. Exploring the action of endoglucanases on bleached eucalyptus kraft pulp as potential catalyst for isolation of cellulose nanocrystals. Int. J. Biol. Macromol. 2019, 133, 1249-1259. [CrossRef] [PubMed]

33. Tibolla, H.; Pelissari, F.M.; Martins, J.T.; Lanzoni, E.M.; Vicente, A.A.; Menegalli, F.C.; Cunha, R.L. Banana starch nanocomposite with cellulose nanofibers isolated from banana peel by enzymatic treatment: In vitro cytotoxicity assessment. Carbohydr. Polym. 2019, 207, 169-179. [CrossRef] [PubMed]

34. Yassin, M.A.; Gad, A.A.M.; Ghanem, A.F.; Abdel Rehim, M.H. Green synthesis of cellulose nanofibers using immobilized cellulase. Carbohydr. Polym. 2019, 205, 255-260. [CrossRef]

35. Pääkko, M.; Ankerfors, M.; Kosonen, H.; Nykänen, A.; Ahola, S.; Österberg, M.; Ruokolainen, J.; Laine, J.; Larsson, P.T.; Ikkala, O.; et al. Enzymatic hydrolysis combined with mechanical shearing and high-pressure homogenization for nanoscale cellulose fibrils and strong gels. Biomacromolecules 2007, 8, 1934-1941. [CrossRef]

36. Dai, J.; Chae, M.; Beyene, D.; Danumah, C.; Tosto, F.; Bressler, D.C. Co-production of cellulose nanocrystals and fermentable sugars assisted by endoglucanase treatment of wood pulp. Materials 2018, 11, 1645. [CrossRef]

37. Camargo, L.A.; Pereira, S.C.; Correa, A.C.; Farinas, C.S.; Marconcini, J.M.; Mattoso, L.H.C. Feasibility of manufacturing cellulose nanocrystals from the solid residues of second-generation ethanol production from sugarcane bagasse. Bioenergy Res. 2016, 9 , 894-906. [CrossRef]

38. Beltramino, F.; Blanca Roncero, M.; Vidal, T.; Valls, C. A novel enzymatic approach to nanocrystalline cellulose preparation. Carbohydr. Polym. 2018, 189, 39-47. [CrossRef]

39. Grzabka-Zasadzińska, A.; Smułek, W.; Kaczorek, E.; Borysiak, S. Chitosan biocomposites with enzymatically produced nanocrystalline cellulose. Polym. Compos. 2017, 16, 101-113. [CrossRef]

40. Kaschuk, J.J.; Frollini, E. Effects of average molar weight, crystallinity, and hemicelluloses content on the enzymatic hydrolysis of sisal pulp, filter paper, and microcrystalline cellulose. Ind. Crops Prod. 2018, 115, 280-289. [CrossRef]

41. Kaschuk, J.J.; de Alexandria Santos, D.; Frollini, E.; Canduri, F.; Porto, A.L.M. Influence of pH, temperature, and sisal pulp on the production of cellulases from Aspergillus sp. CBMAI 1198 and hydrolysis of cellulosic materials with different hemicelluloses content, crystallinity, and average molar mass. Biomass Convers. Biorefinery 2020, 10, 483-494. [CrossRef]

42. Phanthong, P.; Karnjanakom, S.; Reubroycharoen, P.; Hao, X.; Abudula, A.; Guan, G. A facile one-step way for extraction of nanocellulose with high yield by ball milling with ionic liquid. Cellulose 2017, 24, 2083-2093. [CrossRef]

43. Pacheco, C.M.; Bustos, A.C.; Reyes, G. Cellulose nanocrystals from blueberry pruning residues isolated by ionic liquids and TEMPO-oxidation combined with mechanical disintegration. J. Dispers. Sci. Technol. 2020, 41, 1731-1741. [CrossRef]

44. Babicka, M.; Woźniak, M.; Dwiecki, K.; Borysiak, S.; Ratajczak, I. Preparation of nanocellulose using ionic liquids: 1-propyl-3methylimidazolium chloride and 1-ethyl-3-methylimidazolium chloride. Molecules 2020, 25, 1544. [CrossRef]

45. Jordan, J.H.; Easson, M.W.; Condon, B.D. Cellulose hydrolysis using ionic liquids and inorganic acids under dilute conditions: Morphological comparison of nanocellulose. RSC Adv. 2020, 10, 39413-39424. [CrossRef]

46. Prudêncio, C.; Vieira, M.; Van der Auweraer, S.; Ferraz, R. Recycling old antibiotics with ionic liquids. Antibiotics 2020, 9 , 578. [CrossRef]

47. Tan, X.Y.; Abd Hamid, S.B.; Lai, C.W. Preparation of high crystallinity cellulose nanocrystals (CNCs) by ionic liquid solvolysis. Biomass Bioenergy 2015, 81, 584-591. [CrossRef]

48. Mao, J.; Abushammala, H.; Hettegger, H.; Rosenau, T.; Laborie, M.P. Imidazole, a new tunable reagent for producing nanocellulose, part I: Xylan-coated CNCs and CNFs. Polymers 2017, 9, 473. [CrossRef]

49. Mao, J.; Abushammala, H.; Pereira, L.B.; Laborie, M.P. Swelling and hydrolysis kinetics of Kraft pulp fibers in aqueous 1-butyl-3methylimidazolium hydrogen sulfate solutions. Carbohydr. Polym. 2016, 153, 284-291. [CrossRef]

50. Han, J.; Zhou, C.; French, A.D.; Han, G.; Wu, Q. Characterization of cellulose II nanoparticles regenerated from 1-butyl-3methylimidazolium chloride. Carbohydr. Polym. 2013, 94, 773-781. [CrossRef] [PubMed]

51. Mao, J.; Osorio-Madrazo, A.; Laborie, M.P. Preparation of cellulose I nanowhiskers with a mildly acidic aqueous ionic liquid: Reaction efficiency and whiskers attributes. Cellulose 2013, 20, 1829-1840. [CrossRef]

52. Abushammala, H.; Krossing, I.; Laborie, M.P. Ionic liquid-mediated technology to produce cellulose nanocrystals directly from wood. Carbohydr. Polym. 2015, 134, 609-616. [CrossRef]

53. Grzabka-Zasadzińska, A.; Skrzypczak, A.; Borysiak, S. The influence of the cation type of ionic liquid on the production of nanocrystalline cellulose and mechanical properties of chitosan-based biocomposites. Cellulose 2019, 26, 4827-4840. [CrossRef]

54. Brandt, A.; Gräsvik, J.; Hallett, J.P.; Welton, T. Deconstruction of lignocellulosic biomass with ionic liquids. Green Chem. 2013, 15, 550-583. [CrossRef]

55. Suhas, D.; Gupta, V.K.; Carrott, P.J.M.; Singh, R.; Chaudhary, M.; Kushwaha, S. Cellulose: A review as natural, modified and activated carbon adsorbent. Bioresour. Technol. 2016, 216, 1066-1076. [CrossRef] [PubMed]

56. Moon, R.J.; Martini, A.; Nairn, J.; Simonsen, J.; Youngblood, J. Cellulose nanomaterials review: Structure, properties and nanocomposites. Chem. Soc. Rev. 2011, 40, 3941-3994. [CrossRef]

57. Noor, S.M.; Anuar, A.N.; Tamunaidu, P.; Goto, M.; Shameli, K.; Halim, M.H.A. Nanocellulose production from natural and recyclable sources: A review. IOP Conf. Ser. Earth Environ. Sci. 2020, 479. [CrossRef]

58. Brodeur, G.; Yau, E.; Badal, K.; Collier, J.; Ramachandran, K.B.; Ramakrishnan, S. Chemical and physicochemical pretreatment of lignocellulosic biomass: A review. Enzym. Res. 2011, 2011. [CrossRef] [PubMed]

59. Siró, I.; Plackett, D. Microfibrillated cellulose and new nanocomposite materials: A review. Cellulose 2010, 17, 459-494. [CrossRef] 
60. Bensah, E.C.; Mensah, M. Chemical pretreatment methods for the production of cellulosic ethanol: Technologies and innovations. Int. J. Chem. Eng. 2013, 2013, 719607. [CrossRef]

61. Bali, G.; Meng, X.; Deneff, J.I.; Sun, Q.; Ragauskas, A.J. The effect of alkaline pretreatment methods on cellulose structure and accessibility. ChemSusChem 2015, 8, 275-279. [CrossRef] [PubMed]

62. Chen, X.Q.; Pang, G.X.; Shen, W.H.; Tong, X.; Jia, M.Y. Preparation and characterization of the ribbon-like cellulose nanocrystals by the cellulase enzymolysis of cotton pulp fibers. Carbohydr. Polym. 2019, 207, 713-719. [CrossRef]

63. Squinca, P.; Bilatto, S.; Badino, A.C.; Farinas, C.S. Nanocellulose production in future biorefineries: An integrated approach using tailor-made enzymes. ACS Sustain. Chem. Eng. 2020, 8, 2277-2286. [CrossRef]

64. Hindeleh, A.M.; Johnson, D.J. The resolution of multipeak data in fibre science. J. Phys. D Appl. Phys. 1971, 4, 259-263. [CrossRef]

65. Rabiej, S. A comparison of two X-ray diffraction procedures for crystallinity determination. Eur. Polym. J. 1991, 27, 947-954. [CrossRef]

66. Fattahi Meyabadi, T.; Dadashian, F.; Mir Mohamad Sadeghi, G.; Ebrahimi Zanjani Asl, H. Spherical cellulose nanoparticles preparation from waste cotton using a green method. Powder Technol. 2014, 261, 232-240. [CrossRef]

67. Chen, X.; Deng, X.; Shen, W.; Jiang, L. Controlled enzymolysis preparation of nanocrystalline cellulose from pretreated cotton fibers. BioResources 2012, 7, 4237-4248. [CrossRef]

68. Onkarappa, H.S.; Prakash, G.K.; Pujar, G.H.; Kumar, C.R.; Latha, M.S.; Betageri, V.S. Synthesis and characterization of nanocellulose using renewable resources through Ionic liquid medium. Adv. Nat. Sci. Nanosci. Nanotechnol. 2020, 11. [CrossRef]

69. Filson, P.B.; Dawson-Andoh, B.E.; Schwegler-Berry, D. Enzymatic-mediated production of cellulose nanocrystals from recycled pulp. Green Chem. 2009, 11, 1808-1814. [CrossRef]

70. Lazko, J.; Sénéchal, T.; Bouchut, A.; Paint, Y.; Dangreau, L.; Fradet, A.; Tessier, M.; Raquez, J.M.; Dubois, P. Acid-free extraction of cellulose type I nanocrystals using Brønsted acid-type ionic liquids. Nanocomposites 2016, 2, 65-75. [CrossRef]

71. French, A.D. Idealized powder diffraction patterns for cellulose polymorphs. Cellulose 2014, 21, 885-896. [CrossRef]

72. Borysiak, S. Influence of cellulose polymorphs on the polypropylene crystallization. J. Therm. Anal. Calorim. 2013, 113, 281-289. [CrossRef]

73. Borysiak, S. Influence of wood mercerization on the crystallization of polypropylene in wood/PP composites. J. Therm. Anal. Calorim. 2012, 109, 595-603. [CrossRef]

74. Cheng, G.; Varanasi, P.; Li, C.; Liu, H.; Melnichenko, Y.B.; Simmons, B.A.; Kent, M.S.; Singh, S. Transition of cellulose crystalline structure and surface morphology of biomass as a function of ionic liquid pretreatment and its relation to enzymatic hydrolysis. Biomacromolecules 2011, 12, 933-941. [CrossRef]

75. Li, J.; Wei, X.; Wang, Q.; Chen, J.; Chang, G.; Kong, L.; Su, J.; Liu, Y. Homogeneous isolation of nanocellulose from sugarcane bagasse by high pressure homogenization. Carbohydr. Polym. 2012, 90, 1609-1613. [CrossRef]

76. Wang, Y.; Wei, X.; Li, J.; Wang, F.; Wang, Q.; Zhang, Y.; Kong, L. Homogeneous isolation of nanocellulose from eucalyptus pulp by high pressure homogenization. Ind. Crops Prod. 2017, 104, 237-241. [CrossRef]

77. Costa, M.N.; Veigas, B.; Jacob, J.M.; Santos, D.S.; Gomes, J.; Baptista, P.V.; Martins, R.; Inácio, J.; Fortunato, E. A low cost, safe, disposable, rapid and self-sustainable paper-based platform for diagnostic testing: Lab-on-paper. Nanotechnology 2014, 25. [CrossRef] [PubMed]

78. Mohd, N.; Draman, S.F.S.; Salleh, M.S.N.; Yusof, N.B. Dissolution of cellulose in ionic liquid: A review. AIP Conf. Proc. 2017, 1809. [CrossRef]

79. Endres, F. Physical chemistry of ionic liquids. Phys. Chem. Chem. Phys. 2010, 12, 1648. [CrossRef]

80. Miao, J.; Yu, Y.; Jiang, Z.; Zhang, L. One-pot preparation of hydrophobic cellulose nanocrystals in an ionic liquid. Cellulose 2016, 23, 1209-1219. [CrossRef]

81. Yang, H.; Yan, R.; Chen, H.; Lee, D.H.; Zheng, C. Characteristics of hemicellulose, cellulose and lignin pyrolysis. Fuel 2007, 86, 1781-1788. [CrossRef]

82. Lu, P.; Hsieh, Y. Lo Preparation and properties of cellulose nanocrystals: Rods, spheres, and network. Carbohydr. Polym. 2010, 82, 329-336. [CrossRef] 